\title{
Literature Review on the Hellenic Auditing and Accounting Environment before, during and after the Crisis Period
}

\author{
Yiannis K. Yiannoulis \\ Department of Accounting and Finance, School of Economics and Management, Greece
}

Copyright $\mathrm{C} 2019$ by authors, all rights reserved. Authors agree that this article remains permanently open access under the terms of the Creative Commons Attribution License 4.0 International License

\begin{abstract}
The purpose of this paper is to examine the literature regarding the accounting and auditing environment in Hellas; Hellas is a natural experiment in the sense that has characteristics that substantially differ from the major European countries. "For example, the mandatory adoption of International Financial Reporting Standards (IFRS) on January 1, 2005 aimed to improve the quality of financial reporting in Greece, which had been regularly criticized for earnings management and the ineffectiveness of external auditing" (Tsipouridou and Spathis, 2012, Abstract). In addition, Hellas faced a 10-year economic crisis (2008-2018) which affected/changed the Hellenic corporate and capital market environment. For the years before the crisis and the implementation of IFRS, empirical studies showed that Hellas had the one of the highest levels of earnings management (Bhattacharya et al., 2003 and Leuz et al., 2003). All these features are examined in this article in order to gain insight regarding the quality of Hellenic financial reporting and to investigate the changes that crisis had on financial statements quality. The conclusion is that crisis exaggerated problems that already existed in Hellenic corporate environment.
\end{abstract}

Keywords Accounting, Auditing, Hellas, Athens Stock Exchange (ASE)

\section{Introduction}

Last ten years (starting around 2008) Hellas faced three major financial events that affected capital market and Hellenic corporate environment; that is, the:

i) implementation of International Financial Reporting Standards on listed companies (for financial statements published after $1^{\text {st }}$ January 2005),

ii) global financial crisis (started in the USA in 2007) and iii) Hellenic debt crisis.

In this research paper I will review the literature regarding the development of Hellenic capital market (Athens Stock Exchange, ASE, www.helex.gr) and the quality of audit in publicly listed companies, as prescribed by the term "audit gap". That term specifies and characterizes the growing concern of public, regulators and investors regarding the auditor reporting credibility.

These two topics have been isolated and examined from previous researchers in depth; however, the novel thing of this study is that it examines the "audit gap", which is the gap between the expectations that public has from auditors and what auditors actually do in their reports. This term is also examined in accordance with earnings management, which raises the public concerns about the quality of financial information provided in financial statements by managers and audited by qualified and certified auditors.

The topics investigated are crucial and extremely important as they affect capital providers' decisions to invest; in addition, these help the regulators to recognize and prevent bad economic behavior that will hurt public trust and confidence over financial reporting.

The number of Hellenic listed companies is diminishing every year and from 350 companies in 2000 to now exist less than 200 (the half!!). This phenomenon, "delisting" is based on voluntary and involuntary delisting and happens and in other exchanges internationally ("listing gap"). Regarding Hellas a study by Balios et al., (2015) examined for the companies that were listed in ASE on $1^{\text {st }}$ of Janouary 2005 what was their status (listed, delisted voluntarily or delisted involuntarily) on 31 December 2012. Their sample was 239 companies, of which 11 were voluntarily delisted and 42 were delisted by stock market authorities (involuntary delisting). The authors found that "companies with poor liquidity, high leverage, big stock price decline and lack of interest from the investors for the company (low trading activity) have higher probability to be delisted" (Balios et al., 2015, p.69). 
According to my opinion the main reason for this is poor corporate governance attributed to Hellenic listed on ASE firms and the fact that in the years from 1996 to 2004, and especially 1999 and 2000, many companies entered the stock market but they did not fulfill investors' expectations.

Research studies in Corporate Governance in Hellas have shown medium to low compliance to International Corporate Governance Codes (Spanos, 2005 and Florou and Galarniotis, 2007).

Hellas is a small continental Europe country; it has many socio-political features that distinguish the specific country (Hellas) from other European companies. In my opinion, it has been under-researched in these topics and we will try to fill that with our research. Hellenic cultural, political and economic environment is being influenced by Eastern and Western influences (Caramanis, 2005).

Hellenic culture, politics and economics have the influences of many forces (Ballas et al., 1998); "Hellas is considered to be a low trust society with strong preference for stat regulation" (Ballas et al., 2012, p. 53). In addition, as i) owners are involved in management and ii) finance is mainly provided mainly by banks, there is lower need for financial information in order to take financial decisions. Owners can themselves monitor and motivate directors without incentive plans and financial reporting is closely linked to taxation (Ballas et al., 2012, p. 53).

Regarding earnings management Leuz et al. (2003) and Bhattacharya et al. (2003) found that Hellenic companies manipulate their accounting numbers more compared to other European countries.

In the next section we will examine the main aspects of the Hellenic corporate environment and then we will discuss the main developments in Athens Stock Exchange. In the fourth section we will review the literature regarding Hellenic capital market, while in the next section we will examine the very important issue (the main contribution of this paper) of "auditor gap" in Hellas. In the sixth section we will show how the adoption of International Financial Reporting Standards (IFRS) on $1^{\text {st }}$ of January 2005 affected the earnings management behavior of Hellenic listed companies; lastly, in the next section we will report the concluding remarks of this study.

\section{Hellenic Corporate Environment}

One of the main characteristics of the Hellenic corporate environment is the family control of major listed firms; however, this is not a Hellenic phenomenon. We see it across European countries - especially in Continental Europe (Faccio and Lang, 2002). In these countries, where the main ownership structure is control by a family (that also plays a very active role in management), the agency problem of Corporate Governance is how to align the interests of strong controlling and weak minority shareholders (Fama and Jensen, 1983 and Jensen and Meckling, 1976).

A very common argument in favor of family firms is the reduction of "classical" principal/agent agency costs as the owner (family) and management belong to the same family. On the contrary, family firms face significant costs; for example, family owners could expropriate minority shareholders ${ }^{1}$.

Regarding Corporate Governance $(\mathrm{CG})^{2}$ as Spanos et al., (2008, p. 467) state "Although improvements in CG have occurred in Greece, they are mainly confined to a small number of listed companies that are more in tune with the international corporate stage (Tsipouri and Xanthakis, 2004; Spanos, 2005)". A study by Dimitropoulos and Asteriou (2010) reaches the same conclusions.

A study by Ballas et al., (2012) examined the accounting treatment regarding unrealized results (gains or losses) and the capital market reaction to mark to market accounting policy choice of equity investments of Hellenic firms during the period 2002-2004 (before the adoption of IFRS). In order to reduce losses from the decline of ASE General Index of that period most firms choose to adopt different policy for gains and losses. Specifically, listed firms choose to take valuation gains to the income statement and losses through equity; however, this treatment of capital losses affects negatively the stock market investors.

In the next two topics we will describe the capital market environment and capital market research regarding Athens Stock Exchange (ASE).

\section{Capital Market (Athens Stock Exchange - ASE, www.athex.gr) Developments}

Ownership dispersion in Hellas is middle to low; among French civil law countries, in La Porta et al., (1999), Hellas showed average ownership concentration ${ }^{3}$ around $70 \%$. In a similar vein a study of Hellenic Capital Market Commission (HCMC) in 370 listed in 2001 firms showed average dispersion of around $50 \%$ when the major shareholder owns at least 5\%, while dispersion is $35 \%$ when the major shareholders owns at least $1 \%$.

Regarding Corporate Governance laws, Hellas introduced ${ }^{4}$ the "comply or explain" principle with Law

1For a detailed review of the literature on family firms see Spanos et al., (2008), p. 466-8.

2See Table XXX for the development in codes and laws for the Hellenic capital market.

3As a measure of ownership concentration the authors define the average and median ownership percentage of the three largest shareholders for the ten, non-financial, largest in capitalization listed firms.

4 Hellas has followed EU Directives 2006/46/EC and 2007/63/EC (Koutooupis, 2012; Neratzidis, 2015 and Neratzidis et al., 2015). 
$3873 / 2010$; this law obliged "listed companies to disclose an annual corporate governance statement (CGS) in their annual report" (Neratzidis and Tsamis, 2017, p. 366). However, in countries with concentrated ownership structure (like Hellas and Continental Europe countries), large dominant shareholders control management and expropriate minority shareholders in order to extract private control benefits. In that case, the question is how to align the interests of strong block-holders and weak minority shareholders (Spanos, 2005, p. 16). The cost of involvement with management and control for the minor stockholder is greater than the cost of exit; for that reason, they choose to sell stock (use their exit option) if they do not agree with management choices. However, the lack of market for corporate control (capital market liquidity) poses problems in the effectiveness of the shareholders exit option.

But what about Hellenic capital market efficiency? Dicle and Levendis (2011, p. 245, Conclusion) show that "a small percentage of the Greek market may be blamed for market level results that may question market efficiency. These are usually smaller and less liquid stocks". In addition, previous studies (Alexakis and Xanthakis, 1995; Coutts et al., 2000; Mills et al., 2000; Tsangarakis (2007); Al-Khazali et al., 2008 and Kainourgios and Samitas, 2008) examined then ASE for the day of the week effect. They found "evidence of a persistent DOW effect, however for inconsistent weekdays" (Dicle and Levendis, p.231, Literature review, last paragraph).

In the next section, the capital market research will show that ASE's listed firms are mainly family firms with at least five major shareholders.

\section{Capital Market Research in ASE}

According to Tsipouridou and Spathis (2014, p. 39) "The significant expansion of the Athens Stock Exchange (ASE) in the late 1990s turned many firms from private-family owned businesses to publicly listed entities (Spanos, 2005) without changing the existing relatively high levels of family ownership concentration (Lazarides, 2010)."

Spanos et al., (2008) examined ${ }^{5}$ a sample of 120 listed in ASE companies from which 98 were family firms and the rest non-family firms; they found that most of the family firms lack proper corporate governance and especially in: a) risk management, b) board of directors'

5They used a questionnaire that consisted of 54 questions, which were integrated into 37 indicators in five main categories: I) rights and obligations of shareholder (six indicators), II) transparency, disclosure of information and auditing (nine indicators), III) Board of Directors composition (twelve indicators), IV) executive management (five indicators) and V) Corporate Governance commitment, the role of stakeholders and corporate social responsibility (five indicators). independence, c) board committees (i.e. audit committee) and directors remuneration information.

Regarding the interrelationships between ownership structure and board characteristics of Hellenic listed companies Bekiris (2013), for a sample of companies listed in ASE for the period 2000 to 2006, found that in companies where the Chief Executive Officer (CEO) is also Board chairman (weakening Corporate Governance compliance) the independent directors and blockholder ownership tend to be lower. What is more interesting in that research is the fact there is a negative relationship between managerial ownership and board size; this is not in line with agency theory which suggests that managers will generate private profits by adopting a larger board ${ }^{6}$.

As far as the compliance of Hellenic listed on ASE companies with IFRS disclosure requirements is concerned, Tsalavoutas and Dionysiou (2013) found that for 2005 companies applied the relevant requirements of IFRS regarding goodwill (IFRS 3 and International Accounting Standard (IAS) 36) in 70\% and $49 \%$ respectively; Ballas and Tzovas (2010) found similar results for 2006. Baboukardos and Rimmel (2014) examined specifically the relevance of goodwill disclosures under IFRS for the fiscal year 2008 (companies listed on ASE on April $30^{\text {th }}$, 2009); their dependent variable was the market value of equity four months after the company's fiscal year end. They found that purchased goodwill disclosures and "fair value" accounting (FVA) under IFRS were value relevant. A possible explanation of this is that ASE in not "fully efficient" and "the application of FVA may enhance the decision usefulness of financial reporting" (Baboukardos and Rimmel, 2014, p. 12, last paragraph).

Hellas is a code-law, continental Europe country with a "stakeholder-oriented and taxation driven national accounting system (Ballas et al., 1998; Nobes 2008, 2011)" (Baboukardos and Rimmel, 2014, p. 2, last paragraph).

In the next section I will focus on the corporate audit environment which is fundamental in the relationship between companies, regulator authorities and investors.

\section{5. "Auditor Gap" Research}

Hellenic accounting setting is mainly tax-based and conservative (Ballas, 1994, Spathis and Georgakopoulou, 2007). Financial statements are not the main source of information; banks are the main capital providers and "they often develop personal relationships with the firms (Tzovas, 2006). In the relationship-based system, banks may arrive at their credit decisions based on information obtained directly from the owners of the firms, thereby undermining the importance of public accounting information (Tzovas,

6This finding is in line with Lasfer (2003). 
2006)" (Tsipouridou and Spathis, 2014, p. 39).

Regarding audit market, in 1955 corporate auditing was first introduced with the establishment of the Body of Sworn Accountants (Soma Orkoton Logiston - SOL in Greek). Individual auditors were described by Ballas (1994, p. 117, fourth paragraph) as "civil functionaires" , entitled to significant priviledges ${ }^{8}$ (Dedoulis and Caramanis, 2007). In 1992, auditing profession was liberalized; a new public legal entity was created (Body of Certified Auditors and Accountants, Soma Orkoton Elegkton Logiston - SOEL in Greek). Most of SOL members introduced SOL S.A. a new audit firm, which dominated the audit market, despite "Big 4" and other international and national firms. Audit profession has been criticized regarding their reporting credibility (Leventis et al., 2011). In 2003, the supervision of auditors was transformed from SOEL to ELTE (Accounting and Auditing Oversight Board).

But what was the effect of Arthur Andersen's (AA) collapse in September 2002 in the audit services market shares of Big-4 audit companies in Hellas? A research by Ballas and Fafaliou (2008) examined the European Union (EU) audit market, of the EU-15 market countries of that time, for the period 1998 to 2004; for the overall sample they found that "concentration" in the aggregate sample increased over time. Regarding Hellas, the market share of SOL S.A. reduced after 2002, which means that the market share of AA was taken by Big-4 international firms and not my a local audit company (SOL S.A.).

A study of Dimitras and Iatridis (2013) showed that "firms that are audited by a big 4 auditor do not necessarily report higher value relevance in the reported financial numbers when confronted with a crisis" (Iatridis and Dimitras, 2013, p. 158)". For that reason, is very important to increase the credibility of audited financial statements especially during this crisis period.

Ballas et al. (2012) concluded "finally despite the reforms of the audit profession in the early 1990s, the quality of audits in Greece is debatable while quality control ${ }^{9}$, legislated in 2004, was never implemented" (Ballas et al., 2012, p. 53).

In the next section, I will examine how the specific accounting and corporate environment characteristics affected Hellas transformation to International Financial Reporting Standards and whether there was a benefit to users of accounting information (i.e. current and potential investors, tax authorities, capital market authorities) from this transformation.

7Ballas (1994, p.116, last paragraph) states that "quasi civil service nature of SOL".

8Ballas (1994, p. 117, second paragraph describes the situation as follows "For many years SOL operated in a cartel-like fashion....The number of auditors was fixed...".

9In 2003 ELTE was established with the duty to examine auditor's work in a sample of $10 \%$ of the total year audits, in order to enhance people's perception of auditors' quality. However, until now (April 2019) it was not implemented.

\section{Earnings Management Research ${ }^{10}$ IFRS Adoption Effect}

A study of Bae et al., (2008) showed that Hellas, among the 15 "old" European Union members, had the second largest difference between its national accounting system and IFRS. For that reason, the change of corporate accounting system was very difficult for accountants and auditors. As Baboukardos and Rimmel (2014) state "In addition, because Greece is a low-trust society ${ }^{11}$, its accounting environment is highly formalistic....... Another important consequence of the highly formalistic environment in Greece is the absence of extensive supplementary disclosure requirements (Baboukardos and Rimmel, 2014, p. 2).

The first study that analyzed and examined the effect of IFRS adoption in financial statements of listed companies was that of an audit company, Grant Thornton in 2006; this study, by taking the published financial statements of 2004-2005 showed that IFRS adoption had: i) an overall ${ }^{12}$ positive impact of around 5\% in equity, ii) a positive impact in firms' annual results through the increase of the useful lives of depreciable fixed assets and iii) a negative impact on financial results through the recognition of deferred tax liabilities and the creation of provision for contingent income tax.

A study of Ballas et al., (2012) examined, for a sample of Hellenic listed in ASE companies for the years 2002 to 2004, the market reaction to investment valuation adjustments; stock prices do not follow firm's decision to charge investments' valuation adjustments to equity instead of the income statement ${ }^{13}$. This means that ASE is an efficient stock market and "investors in the Athens Stock Exchange react negatively to the valuation adjustment that has no cash flow implications and they react negatively to opaqueness in the financial statements, at least with regard to share valuation adjustment" (Ballas et al., 2012, p. 60, Conclusion).

The compulsory transition of financial statements from Hellenic Generally Agreed Accounting Practices (HGAAP) to International Financial Reporting Standards (IFRS) increased their reliability, transparency and comparability (Ballas et al., 2010). However, the study of Karampinis and Hevas (2011) showed that the value relevance of Hellenic

10The literature regarding earnings management was described by Fields et al., (2001).

11Ballas et al. (1998) stated first the expression "low trust society"

12 The positive impact was basically from assets valuation in fair prices, while the negative impact was through the application of: a) IFRS 19 "employee benefits", b) IFRS 26 "accounting and reporting by retirement benefit plans" and c) the provision of bad debt.

13 After the collapse of ASE stock prices the years following 2000 Hellenic Government issued Law 2992/2002 which allowed listed firms to take the valuation adjustment (losses) of their investments, when applying the "lower of cost or market value", through either the income statement or equity. So, when companies had gains from their investments they reported them in the income statement and when they had losses they reported them in equity adjustment. 
financial statements has slightly only improved; specifically, they compared earnings' value relevance and conditional conservatism between i) the last three years of the application of Greek accounting standards and the first three years of IFRS implementation in ASE listed companies and they found insufficient evidence of improvements in these accounting properties after the mandatory adoption of IFRS. On the contrary, Iatridis and Rouvolis (2010) found that the book value of equity and net profit of companies listed on ASE were more value relevant in the first two years of mandatory adoption of IFRS than in 2004, the last year of application of Hellenic Generally Agreed Accounting Principles.

Tsipouridou and Spathis (2014) examined the relation between earnings management and the likelihood of receiving a qualified opinion from the beginning of 2005 till the end of 2011; the companies (around 1500 firm-year observations) belong to nine sectors: metals, construction and materials of construction, food and beverages, travelling and leisure, information technology, communication, trade, personal and domestic products and industrial products and services. The sample showed that unqualified opinions increased, almost doubled, from 2005 to 2010 and then were reduced significantly. This may be explained by the economic crisis that affected companies' sales and profitability and raised qualified audit opinions; regarding the association between earnings management and the likelihood of receiving a qualified (going-concern) opinion the authors do not find supporting evidence.

But what is the effect of financial crisis on earnings manipulation and the quality of published accounting statements? A study by Iatridis and Dimitras (2013) covering the period 2005 to $2011^{14}$, examined five countries in crisis (Portugal, Ireland, Italy, Hellas and Spain) and the effect of IFRS compulsory adoption in 2005; the authors showed that Hellas after the crisis tend to engage in more earnings management in order to improve their profitability which id diminishing due to the crisis/consumption reduction/recession.

The result of the empirical test is that Hellenic companies' financial statements had a "deterioration of value relevance and quality of reported financial numbers during the crisis" (Iatridis and Dimitras, 2013, p. 158). In addition, they showed that Hellenic listed companies that are audited by Big-4 audit companies are less likely to follow earnings management procedures especially before the crisis. However, the European evidence regarding the Big-4 effect on earnings management is inconclusive; Van Tendeloo and Vanstraelen (2008) show that companies audited by Big- 4 audit companies engage in less earnings management, while Maijoor and Vanstraelen (2006) find

14They split the sample in the pre-crisis period (2005-2008) and the crisis period (2009-2011); their sample consisted of i) 66 companies from Portugal, ii) 157 from Spain, iii) 48 from Ireland, iv) 273 from Italy and 245 from Hellas. no evidence regarding the effect of audit by a Big-4 audit company on earnings management.

\section{Conclusions}

Hellas industrialized after World War II and although in early years had a very rapid growth after it faced structural economic problems and stagnation. This was the case until 2001, when Hellas entered the European Monetary Union (EMU); this resulted in the establishment of stable macroeconomic environment with low currency risk. The Athens Stock Exchange (ASE, www.helex.gr) was upgraded to a mature capital market in 2001; for the period 1996 to 1999 ASE shown the highest growth of any other capital market in the developed world and the number of listed companies increased substantially.

Regarding ownership structure, Hellas ranks in the middle of around 50 countries, when ownership is being measured by adding the percentage share of the three largest shareholders in the ten non-financial listed companies (La Porta et al., 1998). A study in 2001 by Hellenic Capital Market Commission (www.hcmc.gr) showed stockholders that own less than $1 \%$ account for almost $35 \%$ of listed companies' share capital; so, dispersion in Hellas is considered lower than the average.

Regarding Corporate Governance enforcement, a study by Tsipouri and Xanthakis (2004), using questionnaire, showed that "there is a weaker compliance on average concerning the role of stakeholders and corporate social responsibility, the organization of CG, the effective role of the independent members of the board (which could be attributed to companies with family control and the small pool of potential independent board members), disclosure of remuneration and risk management (Tsipouri and Xanthakis, 2004, p. 25). The same results were also in studies of: i) Florou and Galarniotis (2007), ii) Lazarides and Drimpetas (2011), and iii) Neratzidis (2015).

The main characteristics of Hellenic corporate environment are "

- High ownership concentration

- Weak investor protection and enforcement

- Insider governance

- $\quad$ Limited capital market

- Not active external mechanisms (e.g. market for corporate control and labor market)

- $\quad$ No distinction between management and ownership

- One-tier boardroom and

- Not active involvement of institutional investors in management or controlling

(Neratzidis and Tsamis, 2017, p. 367)".

The main finding of this study is that Hellenic companies engage in more earnings management than other European countries; in addition, this is not diminishing when the company is audited by a Big- 4 audit company. 
The research is useful for capital market and audit authorities as they should focus more on improving audit work and preparing accounting and auditing standards that prevent earnings management. In addition, this research would be beneficial by potential investors who base their investment decision to reported financial statements which are biased by earnings management.

Future research can examine how stock markets react to companies' earnings management procedures.

\section{REFERENCES}

[1] Al-Khazali, O., M., Koumanakos, E., P. and Pyun, C., S., (2008), "Calendar anomaly in the Greek stock market: stochastic dominance analysis", International Review of Financial Analysis, 17:3, 461-74.

[2] Alexakis, P. and Xanthakis, M., (1995), "Day of the week effect on the Greek stock market", Applied Financial Economics, 5:1, 43-50.

[3] Baboukardos, D. and Rimmel, G., (2014), “Goodwill under IFRS: Relevance and disclosures in an unfavorable environment", Accounting Forum, 38, 1-17.

[4] Bae, K., Tan, H. and Welker, m., (2008), "International GAAP differences: The impact on foreign analysts", The Accounting Review, 83:3, 593-628.

[5] Balios, D., Eriotis, N., Missiakoulis, S. and Vasiliou, D., (2015), "Delisted versus voluntary delisted versus remain listed: an ordered analysis", Applied Economics Letters, $22: 1,66-70$.

[6] Ballas, A., A., (1994), "Accounting in Greece", The European Accounting Review, 3:1, 107-121.

[7] Ballas, A., A., Chalevas, C. and Tzovas, C., (2012), "Market reaction to valuation adjustments for financial instruments: Evidence from Greece", Journal of International Accounting, Auditing and Taxation, 21, 52-61.

[8] Ballas, A., A. and Fafaliou, I., (2008), "Market shares and concentration in the EU Auditing Industry: the effects of Andersen's Demise", International Advances in Economic Research, 14, 485-97.

[9] Ballas, A. A., Hevas, D. and Neil, D., (1998), "The state of accounting and the state of the state", Journal of Management and Governance, 2, 267-85.

[10] Ballas, A., A., Skoutela, D. and Tzovas, C., A., (2010), "The relevance of IFRS to an emerging market: Evidence from Greece", Managerial Finance, 36:11, 931-48.

[11] Ballas, A., A. and Tzovas, C., (2010), "An empirical investigation of Greek firms' compliance to IFRS disclosure requirements", International Journal of Managerial and Financial Accounting, 2:1, 40-62.

[12] Bekiris, F., V., (2013), “Ownership structure and board structure: are corporate governance mechanisms interrelated?" Corporate Governance: The international journal of business in society, 13:4, 352-64.
[13] Bhattacharya, U., Daouk, H. and Welker, M., (2003), "The world price of earnings opacity", The Accounting Review, 78:3, 641-78.

[14] Caramanis, C., V., "Rationalization, charisma and accounting professionalization: Perspectives on the intra-profession conflict in Greece, 1993-2001", Accounting, Organizations and Society, 30:3, 195-221.

[15] Coutts, A., Kaplanidis, C., Roberts, J., (2000), "Security price anomalies in an emerging market: the case of the Athens Stock Exchange", Applied Financial Economics, 10:5, 561-71.

[16] Dedoulis, E. and Caramanis, C., V., (2007), "Imperialism of influence and the state-profession relationship: The formation of the Greek auditing profession in the post-WWII era", Critical Perspectives on Accounting, 18, 393-412.

[17] Dicle, M., F. and Levendis, J., (2011), "Greek capital market efficiency and its international integration", Journal of International Financial Markets, institutions and Money, $21: 2,229-46$

[18] Dimitropoulos, P., E. and Asteriou, D., (2010), "The effect of board composition on the informativeness and quality of annual earnings: Empirical evidence from Greece", Research in International Business and Finance, 24:2, 190-205,

[19] Faccio, M. and Lang, H. (2002), "The ultimate ownership of western European corporations", Journal of Financial Economics, 65:3, 365-395.

[20] Fama, E. and Jensen, M., (1983), "Separation of ownership and control", Journal of Law and Economics, 26, 301-25.

[21] Florou, A. and Galarniotis, A., (2007), "Benchmarking Greek corporate governance against different standards", Corporate Governance: An international Review, 15:5, 979 - 998.

[22] Hellenic Capital Market Committee, (2001), "Ownership dispersion in the Athens Stock Exchange listed companies", Monthly Bulletin, September.

[23] Iatridis, G. and Dimitras, A., I., (2013), "Financial crisis and accounting quality: Evidence from five European countries", Advances in Accounting, incorporating Advances in International Accounting, 29, 154-60.

[24] Iatridis, G. and Rouvolis, S. (2010), "The post-adoption effects of the implementation of International Financial Reporting Standards", Journal of International Accounting, Auditing and Taxation, 19:1, 55-65.

[25] Jensen, M., C. and Meckling, W., H., (1976), "Theory of the firm: managerial behavior, agency cots and ownership structure", Journal of Financial Economics, 3, 305-60.

[26] Karampinis, N., I. and Hevas, D., L., (2011), "Mandating IFRS in an unfavourable environment: The Greek experience", International Journal of Accounting, 46:3, 304-32.

[27] Kenourgios, D., Samitas, A., (2008), "The day of the week effect patterns on stock market return and volatility: evidence from the Athens stock exchange", International Research of Finance and Economics, 15, 78-89. 
[28] Koutoupis, A., G., (2012), "Importing international corporate governance codes in Greek publicly listed enterprises: a case study analysis", International Journal of Organizational Analysis, 20:4, 447-63.

[29] La Porta, R., Lopez-de-Silanes, F. and Shleifer, A., (1999), "Corporate ownership around the world", Journal of Finance, 54, 471-517.

[30] La Porta, R., Lopez-de-Silanes, F., Shleifer, A. and Vishny, R., W., (1998), "Law and finance", Journal of Political Economy, 106, 1113-1155.

[31] Lasfer, A., (2006), "The interrelationships between managerial ownership and board structure", Journal of Business Finance and Accounting, 33:7, 1006-33.

[32] Lazarides, T., (2010), "Corporate governance law effect in Greece", Journal of Financial Regulation and Compliance, $18: 4,370-85$.

[33] Lazarides, T., H. and Drimpetas, E., (2011), "Evaluating corporate governance and identifying its formulating factors: the case of Greece", Corporate Governance: The International Journal of Business in Society, 11:2, 136-48.

[34] Leventis, S., Weetman, P. and Caramanis, C., (2011), "Agency costs and product market competition: The case of audit pricing in Greece", British Accounting Review, 43:2, $112-9$.

[35] Leuz, C., Nanda, D. and Wysocki, P., (2003), "Earnings management and investor protection: An international comparison", Journal of Financial Economics, 69:3, 505-27.

[36] Maijoor, S., and Vanstraelen, A., (2006), "Earnings management within Europe: The effects of member state audit environment, audit firm quality and international capital markets", Accounting and Business Research, 36:1, $33-52$.

[37] Mills, T., C., Siriopoulos, C., Markelos, R., N. and Harizanis, D., (2000), "Seasonality in the Athens stock exchange", Applied Financial Economics, 10:2, 137-42.

[38] Neratzidis, M., (2015), "Measuring the quality "comply or explain" approach: evidence from the implementation of the Greek corporate governance code", Managerial Auditing Journal, 30:4-5, 373-412.

[39] Neratzidis, M. and Filos, J., (2016), "Recent corporate governance developments in Greece", Corporate Governance: The International Journal of Business in Society, 14:3, 281-99.

[40] Neratzidis, M., Filos, J., Tsamis, A., and Agoraki, M., E., (2015), "The impact of the Combined Code in Greek soft law: evidence from 'comply or explain' disclosures", International Journal of Law and Management, 57:5, 445-60.

[41] Neratzidis, M. and Tsamis, A., (2017), “Going back to go forward: on studying the determinants of corporate governance disclosure", Corporate Governance: The International Journal of Business in Society, 17:3, 365-402.

[42] Nobes, C., (2008), "Accounting classification in the IFRS era", Australian Accounting Review, 18:3, 191-8.

[43] Nobes, C., (2011), "IFRS practices and the persistence of accounting system classification", Abacus, 18:3, 267-83.

[44] Spanos, L., (2005), "Corporate Governance in Greece: development and policy implications", Corporate Governance: The International Journal of Business in Society, 5:1, 15-30.

[45] Spanos, L., J., Tsipouri, L., J. and Xanthakis, M., D., (2008), "Corporate governance rating of family firms at the Athens exchange market", Managerial Finance, 34:7, 465-78.

[46] Spathis, C. and Georgakopoulou, E., (2007), "The adoption of IFRS in South Eastern Europe: The case of Greece", International Journal of Financial Services Management, $2: 1,50-63$.

[47] Tsalavoutas, I. and Dionysiou, D., (2013), "Value relevance of IFRS mandatory disclosure requirements", Journal of Applied Accounting Research, 11:3, 213-28.

[48] Tsangarakis, N., V., (2007), "The day-of-the-week effect in the Athens Stock Exchange (ASE)", Applied Financial Economics, 17:17, 1447-54.

[49] Tsipouri, L. and Xanthakis, M., (2004), "Can corporate governance be rated? Ideas based on the Greek experience", Corporate Governance: An International Review, 12:1, 16-28.

[50] Tsipouridou, M. and Spathis, C., (2014), "Audit opinion and earnings management: Evidence from Greece", Accounting Forum, 38, 38-54.

[51] Tsipouridou, M. and Spathis, C., (2012), "Earnings management and the role of auditors in an unusual IFRS context: The case of Greece", Journal of International Accounting Auditing and Taxation, 21, 62-78.

[52] Tzovas, C., (2006), “Factors influencing a firm's accounting policy decisions when tax accounting and financial accounting coincide", Managerial Auditing Journal, 21:4, 372-86.

[53] Van Tendeloo, B. and Vanstraelen, A., (2008), "Earnings management and audit quality in Europe: Evidence from the private client segment market", The European Accounting Review, 17:3, 447-59. 